\title{
CHOLINESTERASE ACTIVITY IN Crassostrea sp. OF NAYARIT (NW MEXICO) COASTAL WATERS
}

\author{
Juan Carlos BAUTISTA-COVARRUBIAS ${ }^{1 *}$, Miguel VILLASEÑOR ${ }^{2}$, Adela BUENO ${ }^{2}$, \\ David GUTIÉRREZ ${ }^{2}$, Domenico VOLTOLINA ${ }^{3 *}$ and Martín Gabriel FRÍAS-ESPERICUETA ${ }^{4}$
}

\footnotetext{
${ }^{1}$ Secretaría de Investigación y Postgrado, Universidad Autónoma de Nayarit. Ciudad de la Cultura Amado Nervo, Tepic, Nayarit, México, C. P. 63155

${ }^{2}$ Unidad Académica de Ciencias Químico Biológicas y Farmacéuticas, Universidad Autónoma de Nayarit. Ciudad de la Cultura Amado Nervo, Tepic, Nayarit, México, C. P. 63155

${ }^{3}$ Laboratorio de Estudios Ambientales, Universidad Autónoma de Sonora-Centro de Investigaciones Biológicas del Noroeste. Apartado Postal 1132, Mazatlán, Sinaloa, México, C. P. 82000

${ }^{4}$ Facultad de Ciencias del Mar, Univ Autónoma de Sinaloa. Apartado Postal 610, Mazatlan, Sinaloa, México, C. P. 82000

*Corresponding authors: juanb@uan.edu.mx and voltolin04@cibnor.mx
}

(Received November 2015; accepted July 2016)

Key words: esterases, tissue-related differences, seasonal differences, geographic differences, organophosphorus insecticides

\begin{abstract}
Cholinesterases (ChE) have been suggested as biomarkers of the presence of organophosphorus insecticides (OP). The activities of these enzymes were determined in abductor muscle, gills and labial palps of oysters collected during the rainy and the dry seasons at eight points of the coastal zone of Nayarit state (NW Mexico), aiming to determine if their variability is related to geographic and seasonal differences in the use of OP. At all stations, ChE mean activity was lower in the dry than in the rainy season, and the muscle had consistently lower values than gills and labial palps. Lower activities were found in Bahía de Banderas, in the southern part of the state, than in the northern stations. This may be explained by the year-round use of OP insecticides in the southern part of the state, whereas herbicides are the most common pesticides used in agricultural areas draining into the northern stations during the rainy season.
\end{abstract}

Palabras clave: esterasas, diferencias en tejidos, diferencias estacionales, diferencias geográficas, insecticidas organofosforados

\section{RESUMEN}

Las colinesterasas (ChE) se han propuesto como biomarcadores de la presencia de plaguicidas organofosforados (OF). Se determinó la actividad de estas enzimas en el músculo aductor, las branquias y los palpos labiales de ostras recolectadas durante los periodos de lluvias y estiaje en ocho sitios de muestreo ubicados en la zona costera del estado de Nayarit (noroeste de México), con la finalidad de determinar si su variabilidad está relacionada con diferencias geográficas o estacionales en el uso de OF. En todas las estaciones, la actividad de ChE resultó menor en estiaje que durante el periodo de 
lluvias, y los valores encontrados en el músculo fueron constantemente menores que en las branquias y los palpos labiales. La actividad de $\mathrm{ChE}$ fue menor en los organismos recolectados en Bahía de Banderas, en la parte sur del estado, que en las estaciones del norte, probablemente debido al uso de OF durante todo el año en el sur, mientras que los herbicidas son los plaguicidas más usados en las áreas agrícolas que descargan sus efluentes en las áreas de muestreo de la parte norte.

\section{INTRODUCTION}

Organophosphorus (OP) and carbamate (CA) insecticides cause a practically irreversible inhibition of acetylcholinesterase (AChE) and other cholinesterases $(\mathrm{ChE})$ activities and a continuous stimulation of the nervous synapses and physiological and behavioral changes. This leads to death of target and of non-target organisms when these compounds reach the aquatic environment. For this reason, ChE activity has been suggested as a biomarker of exposure to these pollutants (Fulton and Key 2001, Mwila et al. 2013), although several studies suggest that this response may be caused also by exposure to other stressors (Dias et al. 2006, Oliva et al. 2012).

Agriculture is an important activity for most coastal states of the Mexican NW. In the state of Nayarit, the area dedicated to irrigated and dryland (rain-dependent) agriculture is $6024 \mathrm{~km}^{2}$, and chemical insecticides are applied in $29.6 \%$ (178310.4 ha) of this area (INEGI 2012). Considering an average use similar to that of the neighboring state of Sinaloa, of between 3 and $3.5 \mathrm{~kg}$ of insecticide/ha/year (Karam 2002), the amount of insecticides used in Nayarit would be in the order of 535 to $623 \mathrm{t} /$ year and, since $62 \%$ of the insecticides used in Nayarit are OP and CA (González et al. 2010), the amount of ChE-inhibiting OP and CA would be between 332 and 386 t/year.

The hydrological regions of Nayarit, PresidioSan Pedro (RH11), Lerma-Santiago (RH12) and Huicicila-San Blas (RH13) to the north, and Ameca (RH14) to the southare named from the main rivers that flow across the state eventually reaching the Pacific Ocean coastline. Together with their tributaries and lesser streams, these rivers drain the most productive agricultural areas of the state carrying pesticides to the coastal zone in amounts and concentrations which depend on their seasonal use and on the varying volumes of agricultural runoff during the dry and the rainy seasons.

Oysters are sessile filter-feeders, and are among the most common organisms used for pollution monitoring programs (De Freitas et al. 2003, Luna et al. 2010). Therefore, as indicated by Zha et al. (2013), the ChE activity of the tissues of local oysters should indicate the degree and the variability of pesticiderelated stress of the coastal environment.

Since the type and amount of pesticides may vary geographically as well as seasonally, depending on local conditions and planned crops (González et al. 2010), the mean ChE activity was determined in oysters obtained in different coastal zones of the state of Nayarit during the rainy and dry seasons.

\section{MATERIALS AND METHODS}

The sampling points Los Murillo (LM), La Boca de Camichín (BC), El Conchal (EC), Miramar (MR), and Platanitos (PL) are located in the Pacific coastal plain, under the influence of the state's main rivers Acaponeta (LM), San Pedro Mezquital and Grande de Santiago (BC), as well as Huicicila and El Naranjo (EC, MR and PL) which drain areas of intensive agriculture. La Peñita de Jaltemba (LP) lies in the same Sierra de la Costa de Jalisco physiographic province as the two southernmost sampling stations La Cruz de Huanacaxtle (LC) and Bucerias (BS). However, LC and BS are located along the Bahía de Banderas coastline (Fig. 1), where tourism is an increasingly important economic activity, although maize, sorghum, tobacco and other main crops are produced through intensive, mainly irrigated agriculture (INEGI 2012).

Oysters tend to adhere to hard substrates and to each other forming clumps of several individuals. Samples (2.5 to $5.5 \mathrm{~cm}$ Crassostrea sp. from four different clumps) were hand-collected at each sampling station at the beginning of September 2008 (rainy season) and end of February 2009 (dry season), and transported to the laboratory in separate plastic bags contained in an ice box. The selected tissues of each oyster were adductor muscles, gills and labial palps (Bocquené et al. 1997, Nardi et al. 2008). One g of each tissue of each oyster was homogenized separately in a 1300-D Polytron at $12000 \mathrm{rpm}$ for one minute in phosphate buffer in a 1:5 ratio $(\mathrm{w} / \mathrm{v})$ (García et al. 2006). 


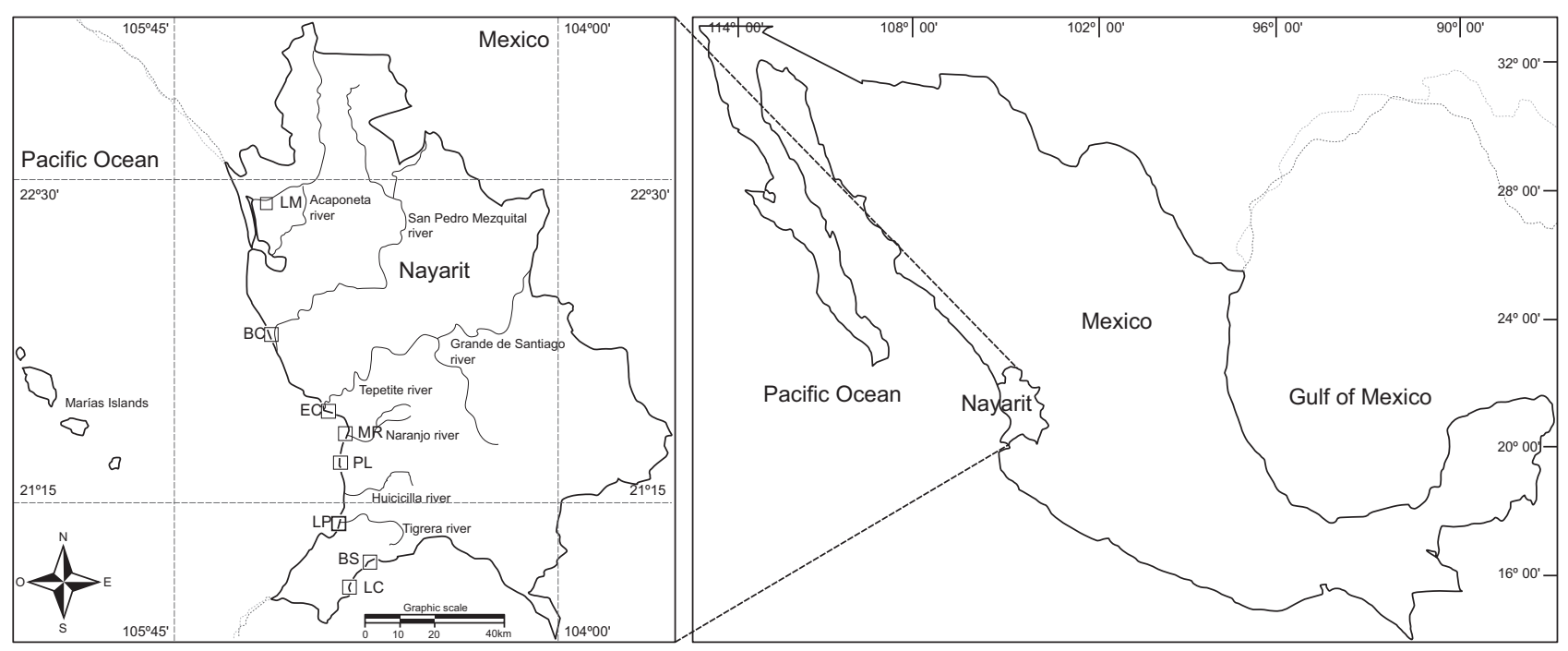

Fig. 1. Sampling points: Los Murillo (LM), La Boca de Camichín (BC), El Conchal (EC), Miramar (MR), Platanitos (PL), La Peñita de Jaltemba (LP), La Cruz de Huanacaxtle (LC), Bucerias (BS)

The resulting suspensions were centrifuged at 10 $000 \mathrm{rpm}$ and $4{ }^{\circ} \mathrm{C}$ for 30 minutes (Beckman GS-15R centrifuge). Four $50 \mu \mathrm{L}$ subsamples of the supernatant were mixed with $250 \mu \mathrm{L}$ of a composite reaction solution of acetylthiocholine $0.075 \mathrm{mM}$ and $10 \mathrm{mM}$ of 5,5 dithiobis-2-nitrobenzoic acid (DTNB), and the ChE activity of each of these mixtures was calculated using two absorbance readings at $414 \mathrm{~nm}$ after 10 and 15 minutes with a Bio-Rad Model 550 plate reader as described by Guilhermino et al. (1996). Proteins were quantified with the Bradford (1976) method, using bovine serum albumin as standard. Bio-Rad reactive was used as a reaction solution in a proportion of 1:4 (v/v) with double distilled water and absorbance readings were made at $595 \mathrm{~nm}$.

Since data were not normal or homoscedastic (Kolmogorov-Smirnov and Bartlett's tests), ChE activities obtained in each station for each tissue were compared with Kruskall-Wallis and Dunn's tests, performed separately for the dry and the rainy season. However, data were normal when the values of all stations were pooled for separate tissue-to-tissue comparison in each season: their mean values were compared with separate one way blocked analysis of variance (ANOVA) tests, and differences were assessed with Tukey's tests. The level of significance was $\mathrm{p}<0.05$ for all tests.

\section{RESULTS}

The general trend of $\mathrm{ChE}$ activity was gills $>$ palps $>$ muscle. With few exceptions, low activities and thus higher inhibitions were determined in both seasons in the northernmost station LM and the southern stations $\mathrm{LC}$ and BS. There were significant differences in the mean activities determined at different stations in the three tissues. In gills, high values were found in both sampling seasons in stations BC, EC and MR. The lowest were in LC and BS, which were significantly different from the value of $\mathrm{BC}$.

In muscle, EC and LP had high activities in the rainy season and the lowest was in $\mathrm{LC}$, while in the dry season $\mathrm{BC}$ and $\mathrm{PL}$ had high values and the lowest was again that of LC. As to palps, the highest values of the rainy season were in $\mathrm{LM}, \mathrm{BC}$ and MR. In this case, LP had the lowest value. In the dry season the high values were in BC and PL and the lowest was that of BS (Table I).

\section{DISCUSSION}

The ChE activities were one order of magnitude higher in the rainy than in the dry season, indicating lower inhibition in summer. This might be due to the prevalent use of insecticides in winter while that of herbicides is more common during spring-summer in the northern stations. However, insecticides are the main type of pesticide used in both planting seasons in the southern part of the state (González et al. 2010). For this reason, although at least in part this difference could be due to fluctuations in enzyme levels and activity in oyster tissues linked to seasonal factors, the most probable explanation for this common seasonal tendency is the dilution effect caused 
TABLE I. MEAN VALUES ( \pm S.E.) OF ChEACTIVITY (nmol/ $\mathrm{min} / \mathrm{mg}$ OF PROTEIN) OF GILLS, PALPS AND MUSCLE OF OYSTERS COLLECTED IN DIFFERENT COASTALAREAS OF NAYARIT STATE IN THE RAINY AND DRY SEASONS $(\mathrm{n}=8)$

\begin{tabular}{lccc}
\hline Station & Gills & Palps & Muscle \\
\hline \multicolumn{3}{c}{ Rainy season } \\
LM & $9.70 \pm 3.57^{a}$ & $17.54 \pm 5.90^{b}$ & $2.79 \pm 1.02^{a b}$ \\
BC & $34.49 \pm 8.27^{b}$ & $14.64 \pm 1.28^{b}$ & $6.62 \pm 0.32^{b c}$ \\
EC & $14.55 \pm 1.55^{a b}$ & $9.27 \pm 2.89^{a b}$ & $12.38 \pm 3.90^{c}$ \\
MR & $15.26 \pm 2.65^{a b}$ & $14.82 \pm 1.21^{b}$ & $2.94 \pm 0.11^{a b}$ \\
PL & $9.69 \pm 0.59^{a b}$ & $10.28 \pm 1.56^{a b}$ & $2.09 \pm 0.32^{a b}$ \\
LP & $11.73 \pm 1.05^{a b}$ & $1.99 \pm 0.26^{a}$ & $9.44 \pm 0.64^{c}$ \\
LC & $8.35 \pm 0.92^{a}$ & $7.11 \pm 0.27^{a b}$ & $1.02 \pm 0.09^{a}$ \\
BS & $7.27 \pm 1.35^{a}$ & $8.62 \pm 0.63^{a b}$ & $2.94 \pm 1.02^{a b}$ \\
\hline & \multicolumn{3}{c}{ Dry season } \\
LM & $0.96 \pm 0.22^{a b}$ & $0.75 \pm 0.02^{a b c}$ & $0.33 \pm 0.06^{a b}$ \\
BC & $2.51 \pm 0.50^{b}$ & $2.30 \pm 0.12^{c}$ & $0.61 \pm 0.25^{a b}$ \\
EC & $1.07 \pm 0.17^{a b}$ & $0.91 \pm 0.05^{b c}$ & $0.43 \pm 0.08^{a}$ \\
MR & $1.98 \pm 0.20^{b}$ & $0.80 \pm 0.15^{a b c}$ & $0.24 \pm 0.07^{a b}$ \\
PL & $1.93 \pm 0.42^{b}$ & $2.17 \pm 0.02^{c}$ & $0.62 \pm 0.08^{b}$ \\
LP & $0.63 \pm 0.01^{a b}$ & $0.28 \pm 0.06^{a b}$ & $0.31 \pm 0.02^{a b}$ \\
LC & $0.43 \pm 0.07^{a}$ & $0.57 \pm 0.01^{a b}$ & $0.22 \pm 0.01^{a b}$ \\
BS & $0.45 \pm 0.02^{a}$ & $0.23 \pm 0.07^{a}$ & $0.04 \pm 0.01^{a}$ \\
\hline
\end{tabular}

Different letters indicate significant differences between stations sampled in the same season (Kruskal-Wallis and Dunn's tests performed separately with the data collected in the rainy and in the dry season, $\mathrm{p}<0.05, \mathrm{a} \leq \mathrm{ab} \leq \mathrm{abc}$ and $\mathrm{a}<\mathrm{b}<\mathrm{c}$ ). (LM) Los Murillo, (BC) La Boca de Camichín, (EC) El Conchal, (MR) Miramar, (PL) Platanitos, (LP) La Peñita de Jaltemba, (LC) La Cruz de Huanacaxtle and (BS) Bucerias

by the high runoff volumes during summer months, as was observed for other contaminants in the San Pedro River by Guzmán et al. (2011).
In spite of the traditional use for fishery, tourism and aquaculture of Nayarit coastal water bodies, information on the presence and levels of contaminants is limited. Páez et al. (2002) and Osuna et al. (2009) found measurable levels of $\mathrm{Pb}$ and $\mathrm{Cd}$ and of some organochlorine pesticides in oysters and mussels of two lagoons of northern Nayarit, and Bernal et al. (2010) determined a low AChE activity in the oysters of one of the stations used in this work (BC). This is the main oyster-producing area of Nayarit State (INEGI 2011), with an estimated 2011 production of $1076 \mathrm{t}$. This station is located in the Marismas Nacionales estuarine system, generated by the confluence of several continental streams which drain some of the state's most productive agricultural areas.

Our data and those of Bernal et al. (2010) coincide in indicating a higher impact of pesticides during the dry than in the rainy season. Additionally, the comparatively high $\mathrm{ChE}$ activity of $\mathrm{BC}$ oysters both in the rainy and in the dry seasons seem to indicate a low local level of impact by agricultural activities in comparison with the rest of the coastal stations selected for this study.

Possibly because of their respiratory function, which causes continuous exposure to water-borne contaminants, it has been suggested that gills may be the appropriate tissue to evaluate the toxic effects of pollutants in laboratory experiments (Bernal et al. 2010, Zha et al. 2013), followed by labial palps and adductor muscle (Bocquené et al. 1997). Although the tendency to higher $\mathrm{ChE}$ values in gills than in muscle corresponds to that reported in other bivalve species, it corresponds only in part with the data of this study, since gills and labial palps had similar activities in either season (Table II).

TABLE II. MEAN VALUES ( \pm S.D.) OF ChE ACTIVITY (nmol $/ \mathrm{min} / \mathrm{mg}$ OF PROTEIN) IN DIFFERENT TISSUES OF MARINE BIVALVES OF CONTAMINATED SITES OR AFTER EXPOSURE TO ORGANOPHOSPHORUS PESTICIDES

\begin{tabular}{lcccc}
\hline Species & Gills & Palps & Muscle & $\mathrm{n}$ \\
\hline Crassostrea gigas $^{1}$ & $28.1 \pm 2.8$ & $13.0 \pm 1.1$ & $6.9 \pm 0.7$ & NA \\
Mytilus galloprovincialis $^{2}$ & $25.3 \pm 7.7$ & NA & $4.5 \pm 0.5$ & NA \\
Ruditapes decussatus $^{*}$ & 0.94 & NA & 0.14 & 4 \\
Crassostrea gigas $^{* 4}$ & $2.8-4.5$ & NA & $0.37-0.5$ & 10 \\
${\text { Crassostrea } \text { sp. }^{5}}_{\text {Crassostrea }^{6}{ }^{6}}^{13.88 \pm 8.79^{\mathrm{b}}}$ & $10.53 \pm 4.99^{\mathrm{b}}$ & $5.03 \pm 4.04^{\mathrm{a}}$ & 48 \\
\hline
\end{tabular}

${ }^{1}$ Bocquené et al. (1997), ${ }^{2}$ Mora et al. (1999), ${ }^{3}$ Nadji et al. (2010), ${ }^{4}$ Ochoa et al. (2013), ${ }^{5}$ This study (rainy season), ${ }^{6}$ This study (dry season). *calculated from bar diagrams. $\mathrm{n}=$ number of specimens analyzed. $\mathrm{NA}=$ data not available. Different letters indicate significant differences among $\mathrm{ChE}$ activities determined in the rainy and dry seasons in this study (One-way block ANOVA and Tukey's tests, $\mathrm{p}<0.05$ ) 
Bivalves such as clams, oysters and mussels are the most common indicators of aquatic pollution (Boening 1997), and their cholinesterase activity has been suggested as biomarker of pesticide pollution (Cajaraville et al. 2000, Damiens et al. 2004). This seems to agree with the values reported in other studies such as Bocquené et al. (1997) and Mora et al. (1999) who reported high activities in oysters and mussels collected in low polluted areas. These results seem to indicate a higher degree of pollution in Nayarit coastal waters during the dry season, while the values determined in the rainy season are close to those reported by Nadji et al. (2010) and Ochoa et al. (2013) in clams and oysters challenged with OP pesticides or transplanted to heavily polluted areas.

However, cholinesterases show a considerable variety of biochemical characteristics, properties and sensitivities to different organic pollutants (Bocquené et al. 1990, 1997). Additionally, they may be affected also by metals, although the effect may be either metal- or species-dependent since, while no effect was observed in mussels exposed to $\mathrm{Cu}$ (Regoli and Principato 1995), Machreki-Ajmi et al. (2008) and Bonacci et al. (2008) observed cholinesterase inhibition in clams when exposed to $\mathrm{Cd}$.

\section{REFERENCES}

Bernal H.Y.Y., Medina D.I.M., Robledo M.M.L., Velázquez F.J.B., Girón P.M.I., Ortega C.L., Maldonado V.W.A. and Rojas G.A.E (2010). Acetylcholinesterase and metallothionein in oysters (Crassostrea corteziensis) from a subtropical Mexican Pacific estuary. Ecotoxicology 4, 819-825.

DOI: $10.1007 / \mathrm{s} 10646-009-0459-2$

Bocquené G., Galgani F. and Truquet P. (1990). Characterization and assay conditions for use of AChE activity from several marine species in pollution monitoring. Mar. Environ. Res. 30, 75-89.

DOI: 10.1016/0141-1136(90)90012-D

Bocquené G., Roig A. and Fournier D. (1997). Cholinesterases from the common oyster (Crassostrea gigas). Evidence for the presence of a soluble acetylcholinesterase insensitive to organophosphate and carbamate inhibitors. FEBS Lett. 3, 261-266.

DOI: 10.1016/S0014-5793(97)00339-6

Boening D.W. (1997). An evaluation of bivalves as biomonitors of heavy metals pollution in marine waters. Environ. Monit. Assess. 55, 459-470.

DOI: 10.1023/A:1005995217901
Bonacci S., Corsi I. and Focardi S. (2008). Cholinesterase activities in the scallop Pecten jacobaeus: Characterization and effects of exposure to aquatic contaminants. Sci. Total Environ. 392, 99-109.

DOI: 10.1016/j.scitotenv.2007.11.029

Bradford M. (1976). A rapid and sensitive method for the quantitation of microgram quantities of protein utilizing the principle of protein dye binding. Anal. Biochem. 72, 248-254. DOI:10.1016/0003-2697(76)90527-3

Cajaraville M.P., Bebianno M.J., Blasco J., Porte C., Sarasquete C. and Viarengo A. (2000). The use of biomarkers to assess the impact of pollution in coastal environments of the Iberian Peninsula: a practical approach. Sci. Total Environ. 247, 295-311.

DOI: 10.1016/S0048-9697(99)00499-4

Damiens G., His E., Gnassia-Barelli M., Quiniou F. and Roméo M. (2004). Evaluation of biomarkers in oyster larvae in natural and polluted conditions. Comp. Biochem. Physiol. 138C, 121-128.

DOI: 10.1016/j.cca.2004.05.010

De Freitas R.M., Rebouças Do A.M.C. and Pfeiffer W.C. (2003). High $\mathrm{Zn}$ and $\mathrm{Cd}$ accumulation in the oyster Crassostrea rhizophorae, and its relevance as a sentinel species. Mar. Pollut. Bull. 46, 1341-1358.

DOI: $10.1016 / \mathrm{S} 0025-326 \mathrm{X}(03) 00244-3$

Dias A.C., Gennari H., Di Mascio P. and Alves E. (2006). In vivo effects of metals on the acetylcholinesterase activity of the Perna perna mussel's digestive gland. Biotemas 19, 35-39.

Fulton M.H. and Key P.B. (2001). Acetylcholinesterase inhibition in estuarine fish and invertebrates as an indicator of organophosphorus insecticide exposure and effects. Environ. Toxicol. Chem. 20, 37-45.

DOI: $10.1002 /$ etc. 5620200104

García L.M., Bautista J.C., Rivera R.N., Betancourt M. and Guilhermino L. (2006). Effects of metamidophos on acetilcholynesterase activity, behavior, and feeding rate of the white shrimp (Litopenaeus vannamei). Ecotox. Environ. Safe. 65, 372-380.

DOI: 10.1016/j.ecoenv.2005.09.001

González A.C.A., Robledo M.M.L., Medina D.I.M., Velázquez F.J.B., Girón P.M.I., Quintanilla V.B., Ostrosky W. P., Pérez H.N.E. and Rojas G.A.E. (2010). Patrón de uso y venta de plaguicidas en Nayarit, México. Rev. Int. Contam. Ambie. 26, 221-228.

Guilhermino L., Lopes C., Carvalho A. and Soares A.M.V.M. (1996). Inhibition of acetylcholinesterase activity as effect criterion in acute test with juvenile Daphnia magna. Chemosphere 32, 727-738.

DOI: 10.1016/0045-6535(95)00360-6

Guzmán C.G., Ramírez L.E.M., Thalasso F., Rodríguez N.S., Guerrero B.A.L. and Avelar G.F.J. (2011). Evaluación de contaminantes en agua y sedimentos del Río 
San Pedro en el estado de Aguascalientes. Universidad y Ciencia 27, 17-32.

INEGI (2011). Perspectiva estadística de Nayarit Diciembre 2011 Instituto Nacional de Estadística, Geografía e Informática. Aguascalientes, México, 89 pp.

INEGI (2012). VIII Censo agrícola, ganadero y forestal 2007. Instituto Nacional de Estadística, Geografía e Informática. Aguascalientes, México, $55 \mathrm{pp}$.

Karam C. (2002). Los agroquímicos: una perspectiva jurídica-ambiental. Análisis del caso Sinaloa. Colegio de Sinaloa. Culiacán, México, 404 pp.

Luna C., Bustamante P., Godefroy J., Fruitier A.I. and Thomas G.H. (2010). Seasonal variation of pollution biomarkers to assess the impact on health status of juvenile Pacific oysters Crassostrea gigas exposed in situ. Environ. Sci. Pollut. Res. 17, 999-1008.

DOI: $10.1007 / \mathrm{s} 11356-009-0287-1$

Machreki-Ajmi M., Ketata I., Ladhar-Chaabouni R. and Hamza-Chaffai A. (2008). The effect of in situ cadmium contamination on some biomarkers in Cerastoderma glaucum. Ecotoxicology 17, 1-11. DOI: $10.1007 / \mathrm{s} 10646-007-0166-9$

Mora P., Michel X. and Narbonne J.F. (1999). Cholinesterase activity as potential biomarker in two bivalves. Environ.Toxicol. Pharmacol. 7, 253-260.

DOI: 10.1016/S1382-6689(99)00019-8

Mwila K., Burton M.H., Van Dyk J.S. and Pletschke B.I. (2013). The effect of mixture of organophosphate and carbamate pesticides on acetylcholinesterase and application of chemometrics to identify pesticides in mixtures. Environ. Monit. Assess. 185, 2315-2327. DOI: $10.1007 / \mathrm{s} 10661-012-2711-0$

Nadji S., Amrani A., Mebarki R. and Khebbeb M.E.H. (2010). Acetylcholinesterase and catalase activities in several tissues of a bivalve mollusc (Ruditapes decussatus) fished from Mellah lagoon (North East of Algeria) after malathion exposure. Ann. Biol. Res. $1,138-144$.
Nardi F., Frati F., Romani R., Rosi G., Corsi I. and Focardi S. (2008). Organophosphate-resistant acetylcholinesterase in Mytilus galloprovincialis: identification of a resistance Ace gene in cerebral ganglion, gills and adductor muscle. Comp. Biochem. Physiol. 151A, S6. DOI: $10.1016 /$ j.cbpa.2008.05.056

Ochoa V., Riva C., Faria M. and Barata C. (2013). Responses of B-esterase enzymes in oysters (Crassostrea gigas) transplanted to pesticide contaminated bays from the Ebro Delta (NE, Spain). Mar. Pollut. Bull. 66, 135-142. DOI: 10.1016/j.marpolbul.2012.09.032

Oliva M., Perales J.A., Gravato C., Guilhermino L. and Galindo R.M.D. (2012). Biomarkers responses in muscle of Senegal sole (Solea senegalensis) from a heavy metals and PAHs polluted estuary. Mar. Pollut. Bull. 64, 2097-2108. DOI:10.1016/j.marpolbul.2012.07.017

Osuna I., Frías M.G., López G., Zazueta H.M., Izaguirre G., Páez F., Ruiz A.C. and Voltolina D. (2009). Cd, $\mathrm{Pb}$ and organochlorine pesticides of Mytella strigata (Pelecypoda: Mytilidae) of six coastal lagoons of NW Mexico. Bol. Invest. Mar. Cost. 38, 233-239.

Páez F., Ruiz A.C., Botello A.V., Ponce G., Osuna J.I., Frías M.G., López G. and Zazueta H.M. (2002). Concentrations of selected trace metals $(\mathrm{Cu}, \mathrm{Pb}, \mathrm{Zn})$, organochlorines (PCBs HCB) and total PAHs in mangrove oysters from the Pacific Coast of Mexico: an overview. Mar. Pollut. Bull. 44, 1303-1308.

DOI: $10.1016 / \mathrm{S} 0025-326 \mathrm{X}(02) 00172-8$

Regoli F. and Principato G. (1995). Glutathione, glutathione-dependent and antioxidant enzymes in mussel, Mytilus galloprovincialis, exposed to metals under field and laboratory conditions: implications for the use of biochemical biomarkers. Aquatic Toxicol. 31, 143-164. DOI: 10.1016/0166-445X(94)00064-W

Zha G., Chen P.V., Luk W.K.W., Zou X., Choi Y.C.R. and Tsim K.W.K. (2013). Characterization of acetilcholinesterase in Hong Kong oyster (Crassostrea hongkongensis) from South China Sea. Chem. Biol. Interactions. 203, 277-281. DOI: 10.1016/j.cbi.2012.09.005 